Bond University

Research Repository

\title{
Ethical consequences of full human genome testing
}

\author{
Lupton, Michael
}

Published in:

US-China Law Review

DOI:

$10.17265 / 1548-6605$

\section{Licence:}

CC BY-NC

Link to output in Bond University research repository.

Recommended citation(APA):

Lupton, M. (2017). Ethical consequences of full human genome testing. US-China Law Review, 14(2), 84-102. https://doi.org/10.17265/1548-6605

\section{General rights}

Copyright and moral rights for the publications made accessible in the public portal are retained by the authors and/or other copyright owners and it is a condition of accessing publications that users recognise and abide by the legal requirements associated with these rights.

For more information, or if you believe that this document breaches copyright, please contact the Bond University research repository coordinator. 


\title{
ETHICAL CONSEQUENCES OF FULL HUMAN GENOME TESTING
}

\author{
Michael Lupton*
}

A Genome is the entire set of hereditary instructions for building, running, maintaining an organism and passing on life to the next generation. A Genome is divided into chromosomes, the chromosomes contain genes and the genes are made of DNA. Genomes are found in cells; which are the microscopic structures that make up all organisms. With few exceptions, each of your body's trillions of cells contains a copy of your genome. The human genome may be commonplace but it is quite powerful, because the information in the genome affects every aspect of a person's behaviour and physiology. The refinement and perfection of the techniques involved has resulted in the reduction of the cost of sequencing to the current price of USD \$1,000 and less. This means that the technology is now routinely available, and it is predicted that in another 5 years' time the tests will cost in the vicinity of USD \$100, placing them on par with the current cost of an X-Ray or a biopsy, and truly within the ambit of an everyday diagnostic tool. The advantages of accurate diagnosis and treatment will be affected by a host of ethical problems. The most pertinent of these are: Incidental findings, confidentiality, responsibility. Incidental genetics findings are unexpected results which are unrelated to the reason for the test. However, if they unearth a gene variant that may cause a serious disease then nondisclosure is hard to justify. If a whole genome sequence reveals a number of clinically actionable variants should this information be passed on to third parties who might also be affected? Alternatively, what happens if the patient insists that the information be kept confidential? Whole genome sequencing will also impact on the concept of responsibility for health. Should such sequencing be used by prospective parents to determine the odds of them transmitting problematic gene variants to their children? If the parents are found to be at risk should they be allowed to resort to pre-implantation genetic diagnosis of their embryos in order to select only healthy embryos for implanting? These and other ethically relevant issues flowing from whole genome sequencing will be discussed in this paper.

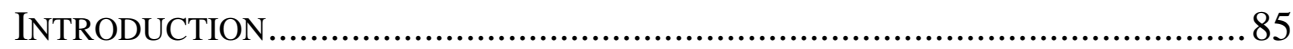

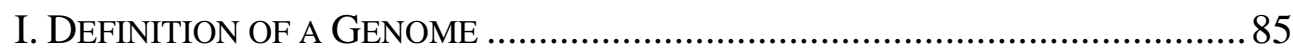

II. ThE Study OF THE Human GenOME................................................ 86

A. Sequencing Versus Analysis .................................................. 86

B. $\quad$ Sequencing Techniques and Cost Reduction ...........................8 87

\footnotetext{
${ }^{*}$ Professor (Bond), Emeritus Professor (Natal), Faculty of Law Bond University, Queensland. F, Gold Coast, Australia. Research fields: Bioethics and Medical Law.
} 
C. Use of Genetic Analysis as a Predictor of Future Diseases....... 88

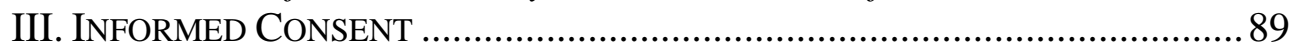

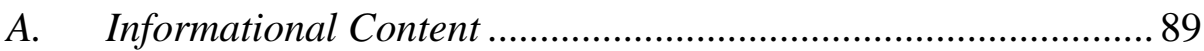

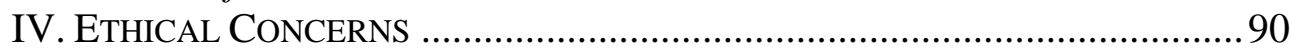

A. $\quad$ Can the Genome Be the Subject of Ownership ...........................90

B. Patenting the Human Genome ..................................................... 91

V. DOCTRINE OF PATIENT AUTONOMY VERSus PROFESSIONAL JUdGMENT IN

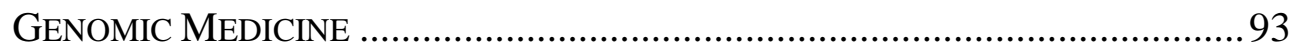

VI. DATA DISCLOSURE, PRIVACY AND DISCRIMINATION ……......................95

A. Obligations to Share Information with Family Members............96

B. Protecting against 'Unfair' Genetic Discrimination...................98

VII. THE ETHICS RELATED TO INCIDENTAL GENETIC FINDING (IFS) ............98

VIII. GENETIC CounSELLING AND WhOLE GENOME SEQUENCING ...............99

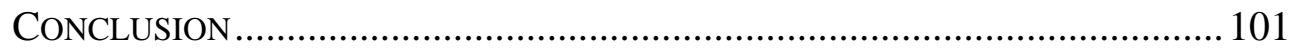

\section{INTRODUCTION}

As the price of whole genome sequencing continues to drop, the consequence thereof is that its use will become increasingly more prevalent by general practitioners. It is not far-fetched to assume that in ten years' time these tests will be as ubiquitous as the current blood tests in the practice of medicine.

Part II of the article will examine the consequences of the continuing lowering of the costs of sequencing the whole genomes while Part III stressed the fact that the necessity for informed consent is undiminished. Part IV examines whether the genome can be the subject of ownership and thus whether it can be patented. Part V discusses the concept of patient autonomy and the professional judgment of doctors in the field of genomic medicine. Part VI stresses the vital importance the laws relating to privacy play in protecting a person's genetic information, while Part VII once again revisits the ethics applicable to incidental genetic findings arriving from sequencing the genome. Part VIII stresses the importance of sound genetic counselling for a patient whose genome has been sequenced.

\section{DEFINITION OF A GENOME}

A genome comprises the entire set of hereditary instructions required to build, run and maintain an organism, inclusive of passing on life to the next generation of that organism. ${ }^{1}$

\footnotetext{
${ }^{1}$ SARah De Weerdt, What Is a Genome? (Editor, Barbara J Culleton, 2003).
} 
The genome of most living organisms is made of a chemical called DNA. The construction of the genome contains genes. The genes in them are packaged in chromosomes and they play a profound role $^{2}$ in creating the specific characteristics of the said organism. ${ }^{3}$ In summary, the genome is divided into chromosomes, the chromosomes contain genes, and the genes are made of DNA. The locus of the genome is in the cells of the organism. These microscopic structures are the building blocks of all organisms. Although the genome is as commonplace as the trillions of cells in your body, which each contain a copy, it is a powerful force in your body. A genome contains information that affects every aspect of a person's physiology as well as its behaviour. Therefore every range and nuance of a person's life, such as thinking, talking, singing, sleeping or digesting food is influenced by that person's genome. ${ }^{4}$

A study of the human genome will reveal insights into why some people die of heart disease while others die of cancer, why some people are confident and extroverted in a crowd while others are shy and retiring. Each human being contains a slightly different version of the human genome, but all human genomes are similar enough that we can learn about the human genome in general by studying the genomes of a few individual people. ${ }^{5}$

\section{THE STUDY OF THE HUMAN GENOME}

Until very recently genetic testing was limited to sequencing single genes. Whole genome sequencing (hereinafter WGS) is also known as full genome sequencing, complete genome sequencing or entire genome sequencing. It involves a laboratory process that determines the complete DNA sequence of an organism's genome in a single process. This process entails sequencing all of an organism's chromosomal DNA as well as the DNA contained in the mitochondria. ${ }^{6}$ WGS enables scientists to identify variants in an individual's genome that may contribute to ill-health. ${ }^{7}$

\section{A. Sequencing Versus Analysis}

Full human genome sequencing (WGS) of an individual's DNA will

\footnotetext{
${ }^{2}$ Ibid.

${ }^{3}$ Ibid.

${ }^{4}$ Ibid.

${ }^{5}$ Ibid.

${ }^{6}$ A. Coombs, The Sequencing Shakeup, 26 NATURAL Biotechnology 1109-1112 (2008).

${ }^{7}$ Carwyn Hooper, The Genome Revolution Is Coming and with Some "Big Dilemmas", THE CONVERSATION (22 June 2015).
} 


\section{ETHICAL CONSEQUENCES OF FULL HUMAN 87}

provide raw data on all six billion nucleotides in an individual's DNA. ${ }^{8}$ Once WGS has been completed the information is provided, then it is available for analysis by experts. This analysis will in turn reveal all the disease-related genetic variants in that genome. The analysis will facilitate a prediction of what diseases a person may be afflicted with in the future. This will allow his physicians to take steps to minimize the impact of that disease or to avoid it altogether through the implementation of personalised preventative medicine. ${ }^{9}$ Jay Flatley, the CEO of Ilumina, has predicted that a WGS for every newborn will be technically feasible and affordable by $2020 .{ }^{10}$ This potential use of genomic sequencing would be controversial as it contradicts established ethical norms for the use of genetic tests. These tests are not normally used to conduct predictive testing on asymptomatic minors. Established ethics dictates that the tests are to be used to identify genetic markers associated with disease. It thus appears that in order to accommodate WGS the medical profession will have to change its traditional norms. ${ }^{11}$

\section{B. Sequencing Techniques and Cost Reduction}

The perfection of high throughput sequencing techniques by 2001 enabled the entire human genome to be sequenced in 10 months at a cost of 5 US cents per base pair. Ongoing improvements in efficiency have meant that the goal now is to reduce the price to below 1 US cent per base pair by $2020 .^{12}$ This goal is likely to be achieved by developing cheaper and quicker ways of preparing DNA for reading by automatic sequencers resulting in fewer passes and assembly issues. Reading techniques will also become cheaper and quicker as a result of a US patent granted on an invention which places DNA on a chip. The chip then passes through on optical detector that records the DNA in much the same way as an optical sensor in a DVD player does. According to its inventors this device has the potential to decipher an entire genome in the 30 minutes and it takes DNA to replicate

\footnotetext{
${ }^{8} \mathrm{SB}$ Ng et al., Exome Sequencing Identifies the Cause of a Mendelian Disorder, 42(1) NATURE GENETICS 30-35(2010).

${ }^{9}$ L. L. McCabe \& E. R. McCabe, Postgenomicmedicine Presymptomatic Testing for Prediction and Prevention, 28 Clinical Perinatal 425-434 (2001).

${ }^{10}$ Mark Henderson, Genetic Mapping of Babies by 2019 Will Transform Preventative Medicine, LONDON TIMES. Online www.timesonline.co.uk/tol/news/uk/science/article 5689052.

${ }^{11}$ P. Barry et al., Genetic Testing in Asymptomatic Minors. Background Considerations, 17 European Journal of Human GenETICS 711 (2009).

${ }^{12}$ T. A. Robertson, The $\$ 1000$ Genome: Ethical and Legal Issues in Whole Genome Sequencing of Individuals, 3(3) AMERICAN JOURNAL OF BIOETHICS 35-42 (2003).
} 
itself. $^{13}$

\section{Use of Genetic Analysis as a Predictor of Future Diseases}

In the early years of the 21 st Century the health industry harboured high expectations that the cures for a raft of as then untreatable diseases would be delivered by the fruits of the Human Genome Project and that cures were just around the corner. This excitement and expectation was driven by the fact that our understanding of the clinical relevance of genetic variants was improving rapidly and that the USD $\$ 1,000$ genome sequence had arrived. We should however retain our rational perspective and not surrender to, nor be blinded by all the hype surrounding genomics. ${ }^{14}$

Scientists require an ongoing flow of money to continue their research. They have seduced the media with wildly extravagant representations of their progress in the field of WGS and the politicians who supply the research dollar have deemed it expedient to jump on the science bandwagon and provide the pump priming dollars that keep the caravan rolling forward. ${ }^{15}$

Let us place genome research into context. In 2007, ten years after the full yeast genome of 6,000 genes had been sequenced 1,000 of those genes had not yet been characterised. As far as humans are concerned the situation is even grimmer, currently the bulk of our biological knowledge (perhaps as high as $99.9 \%$ ) is linked to less than $1 \%$ of the human genome. ${ }^{16}$

It is estimated that roughly 10,000 to 15,000 human genes require functional characterization to get a sound understanding of what the gene protein is all about and to close gaps at the level of molecular, cellular or phenotypic function. ${ }^{17}$

The records show that at current rates of analysis about 100 genes are characterised per year. Why is it so difficult to discover the function of a gene?

First, no molecular function has emerged out of large-scale studies. This is because the specific biological effects of the genes' functions are individual affairs which require creative, gene specific tailored approaches,

\footnotetext{
${ }^{13}$ Op. Cit., at 36.

${ }^{14}$ E. S. Lander et al., Initial Sequencing and Analysis of the Human Genome, 409 NATURE 860 (2001).

${ }^{15} \mathrm{~F}$. Eisenhaber, A Decade after the Firstfull Human Genome Sequencing, When Will We Understand Our Own Genome, 10(5) Journal OF BioInformatics \& Computational Biology (2012).

${ }^{16}$ L. Pena-Castillo \& T. R. Hughes, Why There Are Still Over 1,000 Uncharacterised Yeast Genes? 176 (7) GeNeTiCs 7-14 (2007).

${ }^{17}$ E. Birney et al., Identification and Analysis of Functional Elements in $1 \%$ of the Human Genome by the ENCODE Pilot Project, 447 NATURE 799-816 (2007).
} 
that resist generalised handling. All of these points to the fact that researchers have a long way to go before the large scale personalised medical dream is delivered. ${ }^{18}$

\section{INFORMED CONSENT}

\section{A. Informational Content}

A doctor must obtain informed consent from a patient before he can remove DNA from his body. The informed consent requirement in turn protects the patient's right to decide whether in fact he wishes to provide the doctors with a sample of his tissue. The patient may thus reserve for himself the right not to provide the tissue if the intention is to subject the tissue to tests or for it to be sequenced for purposes unacceptable to the patient. ${ }^{19}$ Consent to removal of tissue per se does not extend to consent or the creation of rights to develop genomic information from that DNA. This denial also extends to the use of DNA retrieved from objects a person has touched or discarded. ${ }^{20}$ The arrival of the $\$ 1,000$ dollars genome (and cheaper) will result in vastly more genetic information being gathered from individuals. It should also serve as a warning to patients to ensure that they obtain legal control over their DNA samples and also over the information they contain. ${ }^{21}$

Informed consent serves as the corner stone of ethical research conduct and aims to protect research subjects against coercion, deception and abuse. ${ }^{22}$ Public policy and ethical guidelines stipulate that the following requirements regarding genetic testing should be met:

- No physician, laboratory or other entity may sequence, store or test identifiable DNA unless the person tested has given written, informed consent.

- Researchers should inform an individual of the relevant risks and benefits of the proposed sequencing and testing prior to taking samples from him.

- The consent must be both free and informed.

\footnotetext{
${ }^{18}$ Ibid.

${ }^{19}$ Welcome Trust Sharing Data from Large-Scale Biological Research Targets. A System of Tripartite Responsibility (2003).

${ }^{20}$ D. M. Wendler et al., Does the Current Consent Process Minimize the Risks of Genetic Research?, 113 AMERICAN JourNAL OF MEDICAL GENETICS 258 (2002).

${ }^{21}$ Ibid.

${ }^{22}$ W. Pinxter et al., Ethical Issues Raised by Whole Genome Sequencing, 28(2) BEST PRACTICE \& RESEARCH ClinicAl GASTROENTEROLOGY 269 (2014).
} 
- $\quad$ The signed consent document also serves the purpose of enabling researchers to defend themselves against accusations of unethical research conduct. ${ }^{23}$

Researchers face the following challenges in obtaining an informed consent:

- The potential for information overload.

- The complexity of the information.

- The limited ability of individuals to sufficiently understand or remember the information given.

- $\quad$ Biased understanding and false hopes.

- A vast volume of complex genetic information.

- The possibility of generating information about the future health status or health risks posed to relatives.

- It would also be ethically correct for researchers to be vigilant in not overselling the benefits of WGS in clinical applications. ${ }^{24}$

\section{ETHICAL CONCERNS}

There is little doubt that a person owns and controls access to his DNA, while the DNA is contained in his body.

Once DNA is removed from a person's body there are immediate legal, social and ethical issues which arise in relation to the control, acquisition and use of that DNA and the information it contains. ${ }^{25}$

The ethical and legal challenges that apply to excised DNA is how to fairly resolve the ownership, consent, privacy, and use of the information revealed by tests on the DNA. A fair resolution of these issues is vital to ensure that consumers and the public will have confidence that whole genome sequencing will benefit rather than harm them. ${ }^{26}$

\section{A. Can the Genome Be the Subject of Ownership}

In order to determine who has ownership (or dispositional control) of an individual's genome it is necessary to distinguish the following issues:

\footnotetext{
${ }^{23}$ Robertson, Op. Cit., at 38.

${ }^{24}$ Pinxter, Op. Cit., at 271-272.

${ }^{25}$ H. Varmus, Getting Ready for Gene-Based Medicine, 347 New England Journal of Medicine 1526 (2002).

${ }^{26}$ Robertson, Op. Cit., at 37.
} 


\section{ETHICAL CONSEQUENCES OF FULL HUMAN 91}

\section{Physical Embodiment}

By physical embodiment we mean a tissue sample that contains the DNA or DNA molecules which have been separated from it. In this instance it is necessary to decide whether to apply a property rule or a liability rule. ${ }^{27}$ If a property rule is chosen a person would have dispositive ownership over the DNA in his body and continue to do so unless or until they abandon their DNA or cede rights in it to third parties. ${ }^{28}$

If a liability rule is used then it would mean that a third party would be required to pay the owner damages for intruding on their body to obtain their DNA and then using it without their consent. The application of this rule would mean that it would not give any rights to third parties in DNA that was taken from the owners' body without informed consent. It would further not create any rights in DNA found on postage stamps, envelopes or cigarette butts. ${ }^{29}$ The leading case of Moore v. Regents of the University of California ${ }^{30}$ adopted a liability, rather than a property approach, to resolve a dispute about the commercial exploitation of a patient's spleen cells. The patient's spleen was removed and his cells used to develop a patented cellline without obtaining the patient's consent to do so. ${ }^{31}$

The court held that Moore (the patient) had a right to informed consent in relation to the removal and use of his cells. The court however rejected his claim that he retained a property right in the tissue after it had been removed from his body. ${ }^{32}$

\section{B. Patenting the Human Genome}

There is great medical importance that attaches to the sequencing of the human genome. The science and testing involved in the process of determining the function of human genes will have consequences regarding the amount of venture capital invested in genetic research and also in turning the results of this research into economic outcomes. In order to achieve these results the law of intellectual property will play a significant role. Without the protection patents offer venture capital investment the

\footnotetext{
${ }^{27}$ B. M. Knoppers et al., The Emergence of an Ethical Duty to Disclose Genetic Research Results: International Perspectives, 14(11) EuROPEAN Journal of HuMAN GENETICs 1170 (2006).

${ }^{28}$ Robertson, Op. Cit., at 37.

${ }^{29}$ Ibid.

${ }^{30} 793$ P (2d) 479 (1990).

${ }^{31}$ Ibid.

${ }^{32}$ Ibid.
} 
genomic revolution will dry up. ${ }^{33}$ The other issue in the field of patents is that scientists have for many years collected samples from the populations in developing countries whose inhabitants have a rich diversity of genetic materials. This material was used to develop therapies which would in turn only be available to the countries of origin under costly licensing agreements. The participating countries are now insisting on a "genomic dividend" for their countries out of the profits derived from their DNA source material. $^{34}$

\section{Patenting the Breast Cancer Gene}

On the 7th October 2015, all seven judges of the High Court of Australia, in the case of D'Arcy v. Myriad Genetics Inc. ${ }^{35}$ overturned the earlier unanimous decision of a five judge bench of the Full Federal Court when they held that an isolated nucleic acid, coding for a mutant BRCA1 protein, was not a "patentable invention" under the Australian Patents Act.

The decision related to Australian Patent no. 686004 which was filed in August 1995 and which had recently expired. The High Court's decision has now closely aligned Australia's position to that of the US Supreme Court in its decision on Myriad Genetics claim for a patent in the USA. ${ }^{36}$

In its decision in Myriad the Full Federal Court had characterised the claimed isolated nucleic acid as a compound rather than information. ${ }^{37}$ In its judgement the High Court differed and held that, to say that the claims relate to a class of chemical compound elevates "form over substance". In the High Court's judgment they held that a sequence of nucleotides, whether genomic DNA or cDNA, should properly be described as "information":

"... the information stored in the sequence of nucleotides coding for the mutated or polymorphic BRCA 1 polypeptide is the same information as that contained in the DNA of the person from which the nucleic acid was isolated. It is the existence of that information which is an essential element of the invention as claimed. The product is the medium in which that information resides." ${ }^{38}$ Myriad did not create this information it already existed in the individual, Myriad merely isolated and extracted the Nucleic

\footnotetext{
${ }^{33}$ Ibid.

${ }^{34}$ Eisenhaber, Op. Cit., at 6 .

${ }^{35}$ [2015] HCA 35.

${ }^{36}$ Association for Molecular Pathology v. Myriad Genetics Inc. 186 L Ed 2d 124 (2013); See also in the U.K. Human Genome Sciences Inc. v. Eli Lilly v. UKSC 5160 [2011].

${ }^{37}$ D'Arcy v. Myriad Genetics Inc. [2014] 313 ALR627. See also, B. Sherman D’Arcy v. Myriad Genetics Inc., Patenting Genes in Australia, 37 (1) Sydney Law Review (2015).

${ }^{38}$ D’Arcy v. Myriad Genetics Inc., Op. Cit., paras. 54-61.
} 


\section{ETHICAL CONSEQUENCES OF FULL HUMAN 93}

acid. The information itself could therefore not be considered a new manner of manufacture. ${ }^{39}$

In this decision the High Court judges in large part have reinvented the test for patentable subject matter formulated in the decision in National Research Development Corporation v. Commissioner of Patents ${ }^{40}$ (NRDC) which was decided in 1959 and which was upheld as recently as 2013 by the High Court in Apotex v. Sanofi Aventis. ${ }^{41}$

The High Court also acknowledged the fact that where a new class of claims such as those in dispute in Myriad arose and which involved negative policy implications which could have the effect of stifling innovation that it was not the role of the Courts but rather that of Parliament to spell out in legislation whether such claims should be patentable. ${ }^{42}$

\section{Effect of the Decision on Gene Patents}

Technological advancements are endemic in the biotechnology industry. In this regard Myriad provides some reprieve to patentees because the High Court (unlike the US Supreme court) has not made prospective statements about gene patents in its judgment. It limited its decision to the specific claims made by the appellant. The High Court also stressed that the decision did not extend to any of the other claims listed in Myriad's Patent on BRCA $1 .{ }^{43}$

Despite the narrow focus of the High Court's decision existing patents based on genetic sequences may now be vulnerable to challenges. IP Australia has also issued a statement that it has suspended the examination of patent applications claiming nucleic acid sequences until it has fully studied the implications of the High Court decision. ${ }^{44}$

In the light of the applicant's victory, it will be interesting to see whether it translates into a reduction of the alleged high cost of breast cancer screening.

\section{DOCTRINE OF PATIENT AUtONOMY Versus PROFESSIONAL JUdGMENT IN GENOMIC MEDICINE}

The evolution away from medical paternalism to patient autonomy is

\footnotetext{
${ }^{39} \mathrm{Ibid}$, at paras. 86-90, 110-113.

${ }^{40}$ [1959] HCA 67.

41 [2013] HCA 50.

${ }^{42}$ D'Arcy v. Myriad Genetics Inc., Op. Cit., paras. 25-28, 135-137.

${ }^{43}$ Ibid, at para. 191.

${ }^{44}$ Ibid.
} 
now firmly entrenched in the ethics of medical practice. Medical practitioners are now trained to respect the individual autonomy of their patients and the fact that a patient has a right to be wrong. However, the dangers of unfettered autonomy are perhaps nowhere greater than in the field of genomic medicine where it could lead to direct genetic testing which in turn could lead to clinically unwise health related decision making. ${ }^{45}$

Professional judgment is more vital than ever given the fact that a patient is able to approach companies that provide WGS on a direct to patient basis.

In most clinical situations the illness being tested for in individuals involves only a selected set of genes that need to be analysed. The analysis of only a selected group of genes will minimise confusion and also reduce the risk of false positive results. ${ }^{46}$

The above situation can be illustrated with the following example. A physician is seeking to establish why a particular patient has a predisposition to cancer. The option of the USD \$1,000 WGS makes it economically feasible to opt for WGS in this diagnostic setting, but it is not professionally responsible to analyse a mass of genes which probably have no bearing on the condition for which the test was ordered. For example, what possible relevance can querying the status of the patients' PSEN1 have (which, when mutated, strongly predisposes a patient to early onset Alzheimer disease) when the required diagnosis is directed at cancer causing mutations. $^{47}$

On the other hand if the object has a research focus, one aimed at gene discovery, then there are clear benefits to be gained from sequencing the entire genome. It is thus clear that professional judgment in the field of genomics is essential for responsibly determining the optimal approach. ${ }^{48}$

The interpretation of WGS results also requires professional knowledge and careful expert planning. Once the results are available a doctor must be able to interpret the results so as to determine what level of evidence is required before assigning pathogenicity to a particular variant of which there will be many. ${ }^{49}$

\footnotetext{
${ }^{45}$ B. M. Knoppers et al., The Emergence of an Ethical Duty to Disclose Genetic Research Results: International Perspectives, 14 EUROPEAN JOURNAL OF HUMAN GENETICS 1170 (2006).

${ }^{46}$ K. L. Brierlyet al., Adverse Events in Cancer Genetic Testing: Medical, Ethical, Legal and Financial Implications, 18 CANCER JOURNAL 303 (2012).

${ }^{47} \mathrm{Ibid}$, at 304 .

${ }^{48}$ E. W. Clayton, Ethical, Legal and Social Implications of Genomic Medicine, 349 NEw ENGLAND JOURNAL OF MEDICINE 562 (2003).

${ }^{49}$ R. Langreth, Fumbled DNA Tests Mean Peril for Breast Cancer Patients, BloOMBERG News (10 September, 2012).
} 


\section{ETHICAL CONSEQUENCES OF FULL HUMAN 95}

It is important for individuals who undergo a genetic sequencing, to have confidence in the recommendations made to them and in the doctors making those recommendations. When such recommendations have clinical implications and are made on the basis of genomic information, then the individual becomes a patient and this interaction becomes part of medical practice which in turn requires the involvement of a licenced health care provider. $^{50}$

The above examples clearly illustrate the fact that clinical judgment is essential in the practice of medicine. As the practice of WGS becomes more common an ever increasing number of high stakes decisions will be made on the basis of complex genomic information. At the current fairly low levels of usage of genomic analysis, misinterpretation of genomic data by medical professionals without adequate genetic knowledge has resulted in a wide range of harm to patients. The consequences have varied from failure to recommend necessary risk-reducing measures for at risk individuals to unnecessary surgery for those actually at normal risk. ${ }^{51}$

It is thus abundantly clear that the aggressive marketing of direct-to consumer genomics, in the absence of expert professional judgment, poses special challenges and should only be sanctioned under regulated circumstances. ${ }^{52}$

\section{DATA Disclosure, PRIVACY AND DisCRIMINATION}

Most ethicists agree that the privacy of individuals undergoing WGS, or more limited genetic sequencing, must be protected at all costs. The reason for this is that the information revealed from such sequencing will not only disclose a great deal of sensitive information about the individual's DNA, his present and future health risks, but it can also reveal information about the DNA sequences of close relatives. ${ }^{53}$

Examples include demographic information, clinical information (or portions of an individual's medical records), exposure of employment histories and family pedigrees amongst other linked data. Such information may be sought by a variety of third parties, including employers, insurers,

\footnotetext{
${ }^{50}$ S. E. Plon et al., IRRC Unclassified Genetic Variants Working Group. Sequences Variant Classifications and Reporting Recommendations for Improving the Interpretation of Cancer Susceptibility Genetic Test Results, 29(11) Human Mutations 1282 (2008).

${ }^{51}$ K. L. Brierley, Op. Cit., at 303.

${ }^{52}$ Ibid.

${ }^{53}$ B. A. Malin, How (Not) to Protect Genomic Data Privacy in a Distributed Network: Using Trail Re-identification to Evaluate and Design Anonymity Protection Systems, 37 Journal OF BIOMEDICAL INFORMATION 179 (2004).
} 
courts of law and family members. The latter parties could all use this information to the detriment of the individual. It is imperative that there are appropriate legal safeguards against such unintended usage. ${ }^{54}$

At the most basic level of protection the person whose DNA is sequenced should have the right to decide whether, and how, identifiable medical information about him is obtained, used, or disclosed to others.

The common law principles of tax and property law will provide some protection, but in Australia, the Privacy Act is likely to provide more substantial protection, especially via Privacy Principle two and three which deal with Anonymity and Pseudonymity, and the collection of solicited personal information. ${ }^{55}$

The Privacy Act makes provision for an individual to pursue both civil $^{56}$ and criminal proceedings ${ }^{57}$ against a third party who sequences, uses or transfers identifiable DNA of another person without that person's permission.

In addition to the above legislation the privacy of genetic information can also be protected via contract. Thus if individuals have dispositional rights over their DNA plus the information originating from that source, then they can refuse to provide DNA for sequencing or testing unless the privacy of the results is protected in terms of the owner's express consent set out in the contractual conditions agreed to when the owner undertook to provide DNA for genotype testing. ${ }^{58}$

Without strong safeguards to ensure privacy, the risk that contributed DNA could be used in unauthorised ways may discourage patients from utilising this ultimate diagnostic tool. ${ }^{59}$

\section{A. Obligations to Share Information with Family Members}

A major risk of sequencing an individual's whole genome is that much more medical information will be known about him and his family than he might find acceptable. Nor would he want others to know about late onset diseases or about behavioural tendencies which he/she could do little to prevent, especially if that information could lead to stigmatization or

\footnotetext{
${ }^{54}$ M. W. Foster \& R. R. Sharp, Ethical Issues in Medical Sequencing Research: Implications of Genotype-Genotype Studies for Individual and Populations, Human MoleCular Genetics 45-49 (2006).

${ }^{55}$ Privacy Act 1988 (Cth) as amended, see especially schedule 1 whichlists The Privacy Principles, and defines them.

${ }^{56}$ See Section 80 (x) of the Privacy Act (1988).

${ }^{57}$ See Section 80 (ZE) of the Privacy Act (1988) (Cth).

${ }^{58}$ Clayton, Op. Cit., at 564.

${ }^{59}$ Robertson, Op. Cit., at 39.
} 


\section{ETHICAL CONSEQUENCES OF FULL HUMAN 97}

discrimination. ${ }^{60}$

The generation of WGS data significantly increases the ability to match the DNA of close relatives, and to reveal predictive information about relatives' present and future health risks. This also raises important questions about what obligations, if any, a patient who has submitted to WGS owes to family members. The probability of, and risks associated with identification, must be balanced against the scientific and clinical usefulness of the data and the rights and autonomy of individuals to participate in genetic research without interference from more risk-averse family members. ${ }^{61}$

The ethical obligations towards relatives increase as the risk to them intensifies. However, in the light of autonomy-based consent principles it seems inappropriate to suggest that participants have a right to deny use of the information. ${ }^{62}$

It is therefore submitted that researchers conducting WGS should, as a matter of course discuss with participants the implications for family members, and they should include close genetic relatives in the decisions about research participation prior to it occurring. The obligation to include at risk relatives in the decision making process increases as the degree of consanguinity with the research participant becomes closer. ${ }^{63}$

If family members raise objections should they be investigated by a relevant research ethics review board? An extensive literature exists on the obligation to warn at risk family members of genetic risks which can be exposed by WGS. ${ }^{64}$

The unauthorised disclosure of genetic risks is only permitted in the most extreme circumstances, and only after attempts to encourage voluntary disclosure on the part of the patient has failed. Furthermore the harm must be highly likely to occur, or be seriously imminent and foreseeable. The at risk relative must be identifiable, the disease preventable, treatable or it

\footnotetext{
${ }^{60}$ E. R. Mardis, A Decades Perspective on DNA Sequencing Technology, 470 NATURE 198 (2011).

${ }^{61}$ American Society of Human Genetics. Professional Disclosure of Familial Genetic Information, 63 AMERICAN JOURNAL OF HUMAN GENETICS 898 (1998).

${ }^{62}$ R. M. Cook-Deacon, Privacy, Families and Human Subject Protections: Some Lessons from Pedigree Research, Journal FOR CONTINUING EduCATION IN HEALTH 224 (2001).

${ }^{63}$ K. L. Hudson, Prohibiting Genetic Discrimination, 356 New England Journal of Medicine 2021 (2007).

${ }^{64}$ K. Offit et al., The Duty to Warn a Patient's Family Members about Hereditary Disease Risks, 292 Journal OF THE AMERICAN MEdicAl Association 1469B (2004). Godard et al., Genetic Information and Testing in Insurance and Employment: Technical, Social and Ethical Issues, II EUROPEAN JOURNAL OF HUMAN GENETICS 5123 (2003).
} 
must be clear that early monitoring will reduce the genetic risk. ${ }^{65}$

\section{B. Protecting against 'Unfair' Genetic Discrimination}

Public opinion is strongly opposed to "genetic discrimination" in the fields of health insurance and employment. This opposition is based on the fear that a person's access to health care and jobs will be impaired by involuntary disclosure. ${ }^{66}$

It is however, accepted that certain existing genetic conditions might predispose some persons to injury in certain industries like beryllium mining. Therefore testing to eliminate such persons from exposure to fatal risks is justifiable. ${ }^{67}$

Access to a person's whole genotype could also result in refusal by insurance companies to sell life and health insurance to an applicant on the basis that it would be to the detriment of other policy holders. Such a refusal would be motivated as protecting existing policy holders against higher premiums by not admitting persons with a much higher genetic risk of illness. The passing of the Genetic Information Non-discrimination Act in the United States will, however, ensure that participants undergoing WGS will not be adversely affected in their access to jobs or health insurance. ${ }^{68}$

The prevalence of identity theft is a growing problem which might discourage many from reducing their "genetic identity" to a computer file which could be stolen and misused. For example, such theft could result in unauthorised testing or disclosures that may lead to stigma and discrimination. The information on the file could also be used to determine identity or kinship relationships that the owner would prefer not to reveal in order to avoid personal embarrassment or legal actions. ${ }^{69}$

\section{The ETHICs RELATED to INCIDENTAL GENETIC FINDING (IFS)}

Incidental findings are the subject of intense ethical debate in medical genomic research. We also need to determine whether this debate is

\footnotetext{
${ }^{65}$ National Institute of Health, Protection of Third Party Information in Research: Recommendations of the NIH (2001). http:/bioethics.od.nih.gov/nihThirdparty rec. html and United States Senate 2003. Genetic Information Non-discrimination Act, s.1053, 108th congress.

${ }^{66}$ K. L. Hudson, Prohibiting Genetic Discrimination, 356 New England Journal of Medicine 2021 (2007).

${ }^{67}$ B. Godard et al., Genetic Information and Testing In Insurance and Employment: Technical, Social and Ethical Issues, II EUROPEAN JOURNAL OF HUMAN GENETICS 5123 (2003).

${ }^{68}$ United States Senate. Genetic Information Non-discrimination Act, s.1053, 108th congress (2003).

${ }^{69}$ R. Williamson \& R. Duncan, DNA Testing for All, 418 NATURE 585-586 (2003).
} 


\section{ETHICAL CONSEQUENCES OF FULL HUMAN 99}

focussed on the right issues. ${ }^{70}$

IF's usually occur when a patient submits to WGS in order to investigate a specific condition. Such widespread testing will, in its very nature, reveal other conditions as well that are unrelated to the reason for the test but which may be clinically relevant. ${ }^{71}$

The ethical issues that arise from such information have implications for patients, researchers and physicians. These implications relate mainly to decisions on how best to prepare patients for the potential discovery of IF's during the informed consent process. The following issues are also relevant:

- Are researchers obliged to report IF's to physicians.

- Do research participants have the right to be informed or not to be informed about IF's. ${ }^{72}$

The answer to these questions depends in part on whether the incidental finding occurs during the course of research or whether it occurs in the context of clinical practice. If the gene variant detected is likely to cause a serious disease and if an early diagnosis will retard the development (or reduce the severity) of the disease, then it is hard to justify nondisclosure. On the other hand, if the clinical relevance of a gene variant is unclear and if there is limited evidence about the predictive variant it is less clear whether such information should be given to the patient. ${ }^{73}$

Withholding health data is reminiscent of medical paternalism which is in stark contrast to the rights of access to health records which 21 st Century patients demand, and this includes the results of any test performed on them. However, withholding certain parts of test results may be construed as a breach of patient autonomy in situations where there is genuine uncertainty about the risks posed by IF's. In such situations a small dose of paternalism may be judicious. ${ }^{74}$

\section{GENETIC COUNSELLING AND WhOLE GeNOME SEQUENCING}

The magnitude and complexity of the information generated by WGS is such that without both pre- and post-test genetic counselling by qualified professionals the test results are of little value to the patient or could

\footnotetext{
${ }^{70}$ S. M. Wolf et al., Managing Incidental Findings in Human Subject's Research: Analysis and Recommendations, 36 JouRnal of LAW AND MEdical ETHICs 219 (2008).

${ }^{71}$ G. M. Christenhus, To Tell or Not to Tell? A Systematic Review of Ethical Reflections on Incidental Findings Arising in Genetic Contexts, 21 European Journal OF HuMAN GENETICS 248 (2013).

${ }^{72} \mathrm{Ibid}$, at 250.

${ }^{73}$ W. Burke et al., Recommendations for Returning Genomic Incidental Findings. We Need to Talk!, 15 GeNETIC MEDICINE 854 (2013).

${ }^{74} \mathrm{Ibid}$, at 856.
} 
actually be dangerous if incorrectly interpreted by a genetic practitioner with only limited training. ${ }^{75}$

The value of competent genetic counselling cannot be overestimated. This fact is illustrated when tests are done for genes which predispose to multifactorial disorders but which convert into only a small risk of disease or for which the precise risk of disease may not even be clearly known. ${ }^{76}$

The above scenario is becoming increasingly more common as genetic tests are being prescribed more often by primary care givers for their patients. In order to avoid problems that can arise for a patient from lack of understanding, the European Commission has endorsed non-directive (noncoercive) genetic counselling as the gold standard. The Commission also recommended that no patient should be permitted to embark on genetic testing without prior counselling. ${ }^{77}$

The availability of direct to consumer genetic testing is indicative of the potential danger lurking in the disconnect between the supply of genetic services on a random basis unaccompanied by any counselling by professionals. For example commercial genetic testing laboratories are now marketing genetic tests for breast cancer (BRCA1 and BRCA2) cystic fibrosis, as well as non-clinical tests for nutrition, directly to consumers. ${ }^{78}$

This strand of direct to consumer marketing has been shown to lead to inappropriate utilization of test results, misinterpretation of results and lack of necessary follow up. The problem is being compounded by internet marketing to consumers plus a variety of 'home testing' kits which are now available. ${ }^{79}$

Unlike the USA, Australia has not yet legislated to control genetic testing or to make counselling mandatory. It has instead relied on the guidelines issued by the Australian Government via the National Health and Medical Research Council. ${ }^{80}$

This document is also reinforced by the guidelines on genetic testing issued by the Australian Medical Association in 2012 entitled "Genetic Testing 2012". Australia and New Zealand have also created guidelines to ensure the quality control of genetic testing done in many laboratories in

\footnotetext{
${ }^{75}$ Conference report Workshop of the Commission of the European Communities on Ethics of Human Genome Analysis: Survey of the European Discussion, 3 Journal of MEdiCAl Genetics 257 (1993).

${ }_{77}^{76}$ Australian Medical Association Genetic Testing 2012, at 4-5.

${ }^{77} \mathrm{Ibid}$, at 258.

${ }^{78}$ A. Surbane, Social and Ethical Implications of BRCA Testing, 22 ANNALS OF ONCOLOGY 160 (2011).

${ }^{79}$ AMA Genetic Testing, at 8 .

${ }^{80}$ Australian Government National Health and Medical Research Council, Uses and Disclosure of Genetic Information to a Patients Genetic Relatives under Section 95 A. A. of the Privacy Act 1988 (Cth).
} 


\section{ETHICAL CONSEQUENCES OF FULL HUMAN 101}

their countries. $^{81}$

For Laboratories to attract a government subsidy for the genetic tests they perform, they must make an application to the Medical Services Advisory Committee which advises the Federal Government on new medical technologies and procedures. ${ }^{82}$

\section{CONCLUSION}

Genetic knowledge can be perceived either as a means to enhance control of person's lives or as a sign of predestination written in a mysterious "future diary" because the full DNA sequence of the human genome now gives us an unprecedented opportunity to observe and understand the Book of Life. ${ }^{83}$

As Genome technology moves from the laboratory to the health care setting the WGS technology will enable geneticists to foretell future disease and alert patients and their health care providers to embark on better preventative strategies. If an individual's WGS analysis falls into the wrong hands it could be used to stigmatise a person or to discriminate against that person. Therefore data control measures and Privacy Laws need to be strengthened to guard against such eventualities. ${ }^{84}$

It is also important to retain a sense of balance in regard to the potential of the Human Genome because of the great expectations that the HGP would lead to massive commercial and medical applications has to date turned out to be over-optimistic and highly inflated. In the words of Francis Collins, "... it is fair to say that the HGP has not as yet directly affected the health care administered to most individuals". ${ }^{85}$ While Craig Venter, the other giant in the field of the HGP, is on record as saying that " $\ldots$ there is still some way to go before this capability can have a significant effect on medicine and health". ${ }^{86}$

The main fruits of the HGP have been accruing to the research community, and almost nothing as yet to medicine and the general public. ${ }^{87}$

\footnotetext{
${ }^{81}$ I. L. Gold et al., Quality and Safety of Genetic Testing in Australia and New Zealand: A Review of the Current Regulatory Framework, 3 Australia AND New Zealand Health Policy (2006).

${ }^{82} \mathrm{Ibid}$.

${ }^{83}$ A. Surbane, Social and Ethical Implications of BRCA Testing, 22 ANNALS OF ONCOLOGY 160, 166 (2011).

${ }^{84}$ M. R Natowics et al., Genetic Discrimination and the Law, 50 AMERICAN JOURNAL OF GENETICS 465 (1992).

${ }^{85}$ F. Collins, Has the Revolution Arrived?, 464 NATURE 676, 677 (2010).

${ }^{86}$ J. C. Venter, Multiple Persons Genomes Await, 464 NATURE 676, 677 (2010).

${ }^{87}$ M. Gisler et al., Innovation as a Social Bubble: The Example of the Human Genome Project, 40 RESEARCH POLICY 1412, 1423 (2011).
} 
When the benefits do start flowing to the field of medical practice it will create a serious demand for medical geneticists and genetic counsellors because inevitably our concept of disease will become increasingly "geneticised". ${ }^{88}$

The new era of personalised medicine based on genomic profiles will demand higher levels of safety, reliability and clinical value for all genetic tests on offer. Patients, their families, and the public must be protected against any untoward social, ethical and legal consequences of genetic testing. Serious consideration should be given to immediately embarking on drafting a Genetic Bill of Rights which will have provisions to regulate and protect all communities for the advent of the genomic age. ${ }^{89}$

\footnotetext{
${ }^{88}$ Conference Report, Op. Cit., at 260.

${ }^{89}$ Ibid.
} 